\title{
Comparative Antibiotic and Probiotic Effects on Antimicrobial Sensitivity of Escherichia coli Isolates and Performance of Broiler Chickens
}

\author{
Cosmas Chikezie $\operatorname{Ogbu}^{1} *$ and Nwabueze Ibeneme ${ }^{2}$ \\ ${ }^{1}$ Department of Veterinary Biochemistry and Animal Production, College of Veterinary Medicine, Michael Okpara \\ University of Agriculture Umudike, Abia State, Nigeria; \\ ${ }^{2}$ Department of Veterinary Services, Ministry of Agriculture Umuahia, Abia State, Nigeria. \\ *Corresponding author Email: ccogbu07@gmail.com
}

\begin{abstract}
The study evaluated the growth performance, haematology, serum biochemistry, intestinal microbial count, and antimicrobial resistance profile of Escherichia coli (E. coli) from broiler chicks fed diets supplemented with antibiotics (neomycin, and oxytetracycline), and probiotic (Saccharomyces cerevisiae). One hundred and twenty Abor acre broiler chicks randomly alloted to four treatment groups (30 birds/group; 10

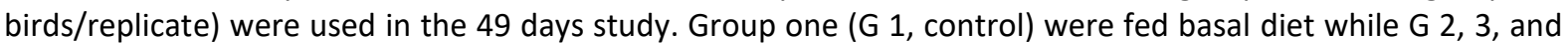
4 received basal diet containing S. cerevisiae $\left(0.80 \mathrm{~g} / \mathrm{kg} ; 10^{8} \mathrm{cfu} / \mathrm{g}\right)$, neomycin $(0.50 \mathrm{~g} / \mathrm{kg})$ and oxytetracycline $(0.30 \mathrm{~g} / \mathrm{kg})$, respectively. Results showed significant treatment effects on body weight, feed intake, linear body values, some haematological indices, intestinal, caecal and combined caecal and intestinal bacteria counts, diameter of E. coli inhibition zone, and mortality. Body weight and feed intake were significantly higher in the supplemented groups. Intestinal bacterial count was highest in neomycin and control groups $(5.29 \pm 0.01$ and $5.22 \pm 0.02 \log _{10} \mathrm{cfu} / \mathrm{ml}$, respectively) while $S$. cerevisiae and neomycin groups yielded the highest caecal, and combined caecal and intestinal bacterial counts. Eimeria Oocyst count did not differ significantly between groups. Escherichia coli from antibiotic fed groups had reduced sensitivity or were resistant to the antibiotics. It was concluded that subtherapeutic use of antibiotics as growth promoters in broiler chickens caused the development of antibiotic resistance, and therefore, should be avoided.
\end{abstract}

Keywords: antimicrobial resistance, growth performance, neomycin, oxytetracycline, S. cerevisiae

\section{Introduction}

Animal productivity is hampered by pathogenic organisms and unfavourable environmental conditions. Intestinal pathogens limit nutrient digestion, absorption, and utilization, as well as depressing immune status and performance and exacerbating other disease condition. Antibiotic growth promoters have been used to boost the performance of broiler chickens by limiting the growth of pathogenic microflora (He et al., 2019). The practice, however, eliminates susceptible bacteria allowing resistant phenotypes to multiply and spread (Neveling et al., 2017).

To stem this tide, the elimination of subtherapeutic in-feed antibiotic growth promoters and the use of alternative feed additives, such as probiotics have been advocated. Sacharomyces cerevisiae (a probiotic) has been extensively evaluated and found effective to enhance the performance of chickens by enhancing intestinal microbial balance and intestinal epithelial development, integrity and function ( $\mathrm{He}$ et al., 2019). Sacharomyces cerevisiae fed in the diet of broiler chickens improved growth rate, feed efficiency, carcass yield and quality, and immune status (Jadhav et al., 2015; He et al., 2019).

The campaign to eliminate antibiotic growth promoters has not been successful due to ignorance of the development of antimicrobial resistance, fear of depressed performance, and high mortality among farmers' livestock who doubt the possibility of efficient production without antibiotic supplementation. There is, hence, a need to demonstrate the effect of antibiotic growth promoters on antimicrobial resistance development and the feasibility of profitable broiler chicken production without in-feed antibiotic growth promoters. The study, 
therefore, aims to evaluate the performance and antimicrobial sensitivity of $E$. coli from broiler chickens fed basal diet, and diets supplemented with antibiotics and a probiotic.

\section{MATERIALS AND METHODS}

\section{Experimental animals and design}

A total of 120 Abor-acre broiler chicks were used for the study. The birds were purchased at day old, brooded until 21 days of age and then randomly allocated (30 birds) to each of four treatment groups (G) with three replicates of 10 birds per group namely control (basal diet, G1), basal diet supplemented with $S$. cerevisiae at $8.0 \times 10^{8} \mathrm{cfug} / \mathrm{kg}(\mathrm{G} 2)$, neomycin at $0.5 \mathrm{~g} / \mathrm{kg}$ (G3), and oxytetracycline at $0.3 \mathrm{~g} / \mathrm{kg}(\mathrm{G} 4)$. They were fed starter mash $(21 \% \mathrm{CP} ; 3100 \mathrm{kcal} / \mathrm{kg}$ $\mathrm{ME})$ during brooding, finisher mash (18\% CP; $2800 \mathrm{kcal} / \mathrm{kg} \mathrm{ME}$ ) until $49 \mathrm{~d}$, and water ad libitum. Management practices and study protocols followed the guideline of the College of Veterinary Medicine Animal Care Ethics Committee (CVM-ACEC).

\section{Measurement of performance variables}

Body weight was obtained weekly by weighing individual birds while feed intake was measured daily. Head circumference, breast girth, neck, keel, body, and thigh lengths were obtained with a measuring tape.

\section{Haematological and serum biochemical indices}

Blood samples were collected from 6 birds per treatment at two weekly intervals for haematological indices (erythrocyte (RBC) count, packed cell volume (PCV), haemoglobin concentration $(\mathrm{Hb})$, total and differential leukocyte (WBC) counts), and at the end of the study (day 49) for serum biochemical indices (albumin, globulin, cholesterol, creatinine, aspartate amino transferase, AST; and alanine amino transferase, ALT).

\section{Aerobic bacteria and Eimeria oocyst counts}

On 49 day old, three birds were randomly selected from each treatment and sacrificed by cervical dislocation for enumeration of intestinal and caecal aerobic bacteria colonies, and Eimeria oocysts. Thoroughly mixed samples of intestinal or caecal or combined caecal and intestinal digester were diluted 1:9 (wt vol $\left.{ }^{-1}\right)$ in peptone water followed by tenfold serial dilution from $10^{-1}$ to $10^{-9}$ for the determination of total aerobic bacteria concentration. Enumeration was done on nutrient agar after incubation at $37^{\circ} \mathrm{C}$ for 48 hours and results expressed as log colony forming units per $\mathrm{ml}$ (log cfu/ml) (Cruickshank, 1975). Eimeria oocysts count was done using the floatation technique (Cheesbrough, 1998) and results expressed as number of oocysts per gram digester (oocyst/g).

Isolation, identification, and antibiotic sensitivity test for Escherichia coli

Thoroughly mixed intestinal digester from each treatment was enriched in thioglycolate broth and incubated at $37^{\circ} \mathrm{C}$ for $24 \mathrm{~h}$ followed by inoculation onto Mackonkey agar, and incubation at $37^{\circ} \mathrm{C}$ for $24 \mathrm{~h}$. Colonies resembling E. coli (round, opaque, rose pink colour, and $1 \mathrm{~mm}$ diameter) were carefully collected, subcultured in Eosin Methylene Blue agar and incubated at $37^{\circ} \mathrm{C}$ for $24 \mathrm{~h}$. Colonies with greenish metallic sheen suggestive of $E$. coli were then subjected to indole, methyl-red, Voges-Proskauer and citrate tests for confirmation of E. coli. Representative E. coli colonies were subcultured in peptone water and incubated at $37^{\circ} \mathrm{C}$ for $24 \mathrm{~h}$. A suspension of the broth culture was gently swabbed over nutrient agar (NA), allowed standing for $4 \mathrm{~min}$ and then incubated at $37^{\circ} \mathrm{C}$ for $3 \mathrm{~h}$. Thereafter, oxytetracycline $(30 \mu \mathrm{g})$ and neomycin $(30 \mu \mathrm{g})$ discs were carefully pressed onto the NA surface and incubated at $37^{\circ} \mathrm{C}$ for $24 \mathrm{~h}$. The zones of inhibition were measured to the nearest millimeter using a caliper and zone 
diameter interpreted following the Clinical and Laboratory Standards Institute guidelines (CLSI, 2013).

\section{Data analysis}

Data were subjected to Analysis of Variance in SPSS version 9.0 and significantly different means were separated using the Duncan Multiple Range Test.

\section{Results and discussion \\ Growth performance}

Birds in the control had the lowest body weight followed by those fed oxytetracycline compared to the groups fed $S$. cerevisiae and neomycin (Table 1).

Body weight gain and feed conversion ratio were not significantly different across dietary treatments. Feed intake did not differ significantly between groups except for day 49 when feed intake was significantly higher in the treated groups compared to the control. The enhanced body weight values observed in the supplemented groups demonstrate the growth enhancing effects of probiotics and antibiotic growth promoters as reported by other studies (Bonsu et al., 2012; El-Hammady et al., 2014; He et al., 2019). The similar body weight of neomycin and probiotic fed birds indicates that probiotics can replace in-feed antibiotics as growth promoters in broiler diets. In the present study, birds fed oxytetracycline had consistently lower body weight than those fed probiotic. This shows that the continued use of some antibiotics could depress growth performance in broiler chickens. He at al. (2019) observed lower body weight gains in broilers fed clotetracycline compared to those fed probiotics. Probiotics enhance growth performance by inhibiting pathogenic intestinal microflora, enhancing beneficial intestinal microflora, intestinal integrity and function, nutrient retention and utilization, immune and health status (Mohamed et al., 2014; Neveling et al., 2017). Saccharomycese cerevisiae is a type of anaerobic bacteria rich in protein, nucleic acid, vitamins, polysaccharides, and other nutrients (He et al., 2019). Its cell wall is believed to be effective in reducing the toxicity of mycotoxins in animals (Jadhav et al., 2015).

Table 1. Effect of antibiotics and probiotic on growth parameters of Abor acre broiler chicks

\begin{tabular}{|c|c|c|c|c|}
\hline Variable & Basal diet & S. cerevisiae & Neomycin & oxytetracycline \\
\hline $\mathrm{BWT}_{21}$ & $586.84 \pm 28.32^{c}$ & $696.43 \pm 17.24^{a}$ & $673.08 \pm 14.74^{\mathrm{ab}}$ & $632.76 \pm 19.42^{b c}$ \\
\hline $\mathrm{BWT}_{28}$ & $831.58 \pm 61.08$ & $946.43 \pm 26.84$ & $976.00 \pm 39.59$ & $882.76 \pm 31.90$ \\
\hline $\mathrm{BWT}_{35}$ & $1129.41 \pm 53.22^{b}$ & $1356.00 \pm 45.85^{a}$ & $1314.00 \pm 25.25^{a}$ & $1210.71 \pm 32.26^{b}$ \\
\hline $\mathrm{BWT}_{42}$ & $1600.00 \pm 56.07^{c}$ & $1833.33 \pm 58.72^{\mathrm{ab}}$ & $1900.00 \pm 35.00^{a}$ & 1698. $00 \pm 46.95^{b c}$ \\
\hline $\mathrm{BWT}_{49}$ & $2113.33 \pm 59.25^{b}$ & $2352.17 \pm 85.70^{\mathrm{a}}$ & $2468.18 \pm 36.86^{a}$ & $2170.83 \pm 45.64^{b}$ \\
\hline $\mathrm{BWG}_{21-28}$ & $36.09 \pm 8.98$ & $35.71 \pm 4.35$ & $43.43 \pm 5.36$ & $35.71 \pm 3.99$ \\
\hline $\mathrm{BWG}_{28-35}$ & $38.24 \pm 8.49$ & $56.12 \pm 6.76$ & $42.57 \pm 7.99$ & $50.74 \pm 7.56$ \\
\hline $\mathrm{BWG}_{35-42}$ & $67.23 \pm 9.49$ & $70.15 \pm 9.00$ & $75.14 \pm 6.68$ & $72.41 \pm 8.30$ \\
\hline $\mathrm{BWG}_{42-49}$ & $68.57 \pm 4.72$ & $70.15 \pm 13.79$ & $71.43 \pm 7.43$ & $75.86 \pm 8.47$ \\
\hline $\mathrm{FI}_{21-28}$ & $84.47 \pm 6.03$ & $94.39 \pm 6.03$ & $87.30 \pm 6.03$ & $86.82 \pm 6.03$ \\
\hline $\mathrm{Fl}_{28-35}$ & $111.18 \pm 6.03$ & $127.12 \pm 6.03$ & $136.95 \pm 6.03$ & $132.65 \pm 6.03$ \\
\hline $\mathrm{FI}_{35-42}$ & $145.82 \pm 6.03$ & $146.29 \pm 6.03$ & $161.57 \pm 6.03$ & $148.35 \pm 6.03$ \\
\hline $\mathrm{FI}_{42-49}$ & $142.86 \pm 6.03$ & $161.71 \pm 6.03$ & $160.56 \pm 6.03$ & $156.01 \pm 6.03$ \\
\hline $\mathrm{FCR}_{21-28}$ & $1.71 \pm 1.31$ & $4.04 \pm 0.69$ & $2.10 \pm 0.35$ & $3.76 \pm 0.54$ \\
\hline $\mathrm{FCR}_{28-35}$ & $2.00 \pm 1.54$ & $2.57 \pm 0.36$ & $1.63 \pm 1.23$ & $2.74 \pm 0.68$ \\
\hline $\mathrm{FCR}_{35-42}$ & $2.49 \pm 0.62$ & $2.13 \pm 0.37$ & $2.57 \pm 0.43$ & $2.22 \pm 0.24$ \\
\hline $\mathrm{FCR}_{42-49}$ & $2.05 \pm 0.20$ & $1.68 \pm 0.71$ & $2.53 \pm 0.42$ & $2.05 \pm 0.42$ \\
\hline
\end{tabular}


The higher feed intake in the supplemented groups at finisher phase (day 49) was necessary to support the enhanced growth rate in these groups while the predominant similarity in feed intakes agrees with He et al. (2019) that in-feed antibiotics and probiotics has no effect on daily feed intake. Some earlier studies (Ashayerizadeh et al., 2009; Toghyani et al., 2011) however, reported significantly higher cumulative feed intake in broiler chickens fed probiotics, prebiotics and antibiotics compared to control while Odefemi (2016) reported higher feed intake in broilers fed probiotics compared to those fed antibiotics. Variations in response to feed additives relate to differences in probiotic species and antibiotic agents, species combination and dose, production standards, environmental factors and management, intestinal ecosystem, as well as inter-microbial and microbiota - host interactions. The similar feed conversion ratio indicates equivalent feed efficiency across treatments which suggests that optimal environmental control eliminates the need for antibiotic supplementation to enhance feed utilization (Gunal et al., 2006).

Comparison of linear body values revealed inconsistent trends over the age periods (Table 2). On day 49 , the head circumference was similar across treatment groups $(P>0.05)$. Neck length was lower in the neomycin group compared to others which had higher and similar values. The control group and the group fed oxytetracycline had similar and higher breast girth than the groups fed neomycin and S. cerevisiae which did not differ significantly. Keel length was lowest in the group fed oxytetracycline and highest in control and neomycin groups. Birds fed S. cerevisiae had a similar final body length as those of the control and oxytetracycline groups, but this was lower compared to that of neomycin group. Birds fed neomycin had the highest final value for thigh length compared to other groups. Similar linear body values between experimental groups indicated similarity in the development of the different body parts of the broiler chickens. Islam et al. (2004) reported no effect of different levels of probiotics on linear body traits of broiler chickens.

Table 2. Effect of antibiotics and probiotic on linear body values of Abor acre broiler chicks

\begin{tabular}{lllll}
\hline Variable & Basal diet & S. cerevisiae & Neomycin & oxytetracycline \\
\hline $\mathrm{HC}_{21}$ & $9.53 \pm 0.17^{\mathrm{b}}$ & $9.96 \pm 0.14^{\mathrm{a}}$ & $9.76 \pm 0.14^{\mathrm{ab}}$ & $10.03 \pm 0.14^{\mathrm{a}}$ \\
$\mathrm{HC}_{35}$ & $13.15 \pm 0.18^{\mathrm{a}}$ & $13.04 \pm 0.15^{\mathrm{a}}$ & $12.56 \pm 0.14^{\mathrm{b}}$ & $12.41 \pm 0.14^{\mathrm{b}}$ \\
$\mathrm{HC}_{49}$ & $13.34 \pm 0.18$ & $13.37 \pm 0.15$ & $13.57 \pm 0.15$ & $13.39 \pm 0.15$ \\
\hline $\mathrm{NL}_{21}$ & $4.42 \pm 0.18$ & $4.59 \pm 0.15$ & $4.60 \pm 0.15$ & $4.59 \pm 0.14$ \\
$\mathrm{NL}_{35}$ & $6.74 \pm 0.19^{\mathrm{b}}$ & $7.24 \pm 0.15^{\mathrm{a}}$ & $6.29 \pm 0.16^{\mathrm{b}}$ & $6.38 \pm 0.15^{\mathrm{b}}$ \\
$\mathrm{NL}_{49}$ & $8.02 \pm 0.19^{\mathrm{a}}$ & $7.84 \pm 0.16^{\mathrm{a}}$ & $7.00 \pm 0.16^{\mathrm{b}}$ & $7.80 \pm 0.16^{\mathrm{a}}$ \\
\hline $\mathrm{BG}_{21}$ & $7.97 \pm 0.24^{\mathrm{b}}$ & $8.86 \pm 0.20^{\mathrm{a}}$ & $8.29 \pm 0.21^{\mathrm{ab}}$ & $7.97 \pm 0.24^{\mathrm{b}}$ \\
$\mathrm{BG}_{35}$ & $12.88 \pm 0.26$ & $12.78 \pm 0.21$ & $12.29 \pm 0.22$ & $12.88 \pm 0.26$ \\
$\mathrm{BG}_{49}$ & $13.33 \pm 0.26^{\mathrm{a}}$ & $12.56 \pm 0.22^{\mathrm{b}}$ & $12.70 \pm 0.22^{\mathrm{b}}$ & $13.33 \pm 0.26^{\mathrm{a}}$ \\
\hline $\mathrm{KL}_{21}$ & $8.79 \pm 0.28^{\mathrm{b}}$ & $9.41 \pm 0.18^{\mathrm{a}}$ & $9.25 \pm 0.19^{\mathrm{ab}}$ & $9.16 \pm 0.18^{\mathrm{ab}}$ \\
$\mathrm{KL}_{35}$ & $12.88 \pm 0.23^{\mathrm{ab}}$ & $12.94 \pm 0.19^{\mathrm{a}}$ & $12.73 \pm 0.19^{\mathrm{ab}}$ & $12.43 \pm 0.18^{\mathrm{b}}$ \\
$\mathrm{KL}_{49}$ & $13.48 \pm 0.23^{\mathrm{a}}$ & $12.76 \pm 0.20^{\mathrm{b}}$ & $13.14 \pm 0.20^{\mathrm{ab}}$ & $12.20 \pm 0.19^{\mathrm{c}}$ \\
\hline $\mathrm{BL}_{21}$ & $16.10 \pm 0.44^{\mathrm{c}}$ & $17.64 \pm 0.37^{\mathrm{a}}$ & $16.42 \pm 0.38^{\mathrm{bc}}$ & $17.31 \pm 0.36^{\mathrm{ab}}$ \\
$\mathrm{BL}_{35}$ & $27.06 \pm 0.47^{\mathrm{ab}}$ & $27.40 \pm 0.39^{\mathrm{a}}$ & $26.21 \pm 0.39^{\mathrm{bc}}$ & $25.95 \pm 0.37^{\mathrm{c}}$ \\
$\mathrm{BL}_{49}$ & $28.77 \pm 0.47^{\mathrm{ab}}$ & $27.63 \pm 0.40^{\mathrm{b}}$ & $29.18 \pm 0.40^{\mathrm{a}}$ & $28.46 \pm 0.39^{\mathrm{ab}}$ \\
\hline $\mathrm{TL}_{2}$ & $5.11 \pm 0.21^{\mathrm{c}}$ & $5.75 \pm 0.17^{\mathrm{ab}}$ & $5.54 \pm 0.18^{\mathrm{bc}}$ & $6.00 \pm 0.17^{\mathrm{a}}$ \\
$\mathrm{TL}_{35}$ & $7.77 \pm 0.22^{\mathrm{bc}}$ & $8.28 \pm 0.18^{\mathrm{a}}$ & $7.38 \pm 0.18^{\mathrm{c}}$ & $7.96 \pm 0.17^{\mathrm{ab}}$ \\
$\mathrm{TL}_{49}$ & $7.98 \pm 0.22^{\mathrm{b}}$ & $7.83 \pm 0.19^{\mathrm{b}}$ & $8.92 \pm 0.19^{\mathrm{a}}$ & $8.20 \pm 0.18^{\mathrm{b}}$ \\
\hline $\mathrm{abc}$ significantly different means on same row $(\mathrm{p}<0.05) ; \mathrm{HC}:$ head circumference, BG: breast girth, NL, KL, BL and TL: neck, \\
keel, body and thigh lengths, respectively. & &
\end{tabular}




\section{Haematological and serum biochemical indices}

Probiotic and antibiotic supplementation did not affect erythrocyte ( $R B C$ ), and white blood cell (WBC) counts, and haemoglobin ( $\mathrm{Hb})$ concentration (Table 3). At day 21 and 49, PCV was higher in the antibiotic groups compared to probiotic group but similar to control group which in turn did not differ significantly from the probiotic group. Birds fed neomycin had significantly $(p<0.05)$ lower percent lymphocytes compared to $S$. cerevisiae group at day 21 while those fed oxytetracycline had lower lymphocytes than probiotic group at day 49. The probiotic and control groups had the highest percent lymphocytes across the age periods. Birds fed antibiotics also had higher heterophils than the probiotic group at these age periods. Ratio of Heterophil to lymphocyte $(H: L)$ was highest $(p<0.05)$ in the antibiotic group at day 21 and 35, and in the oxytetracycline and control groups at day 49 compared to the group fed $S$. cerevisiae. The non-significant effect of treatments on RBC and WBC counts, and $\mathrm{Hb}$ concentration agrees with Tang et al. (2017) who reported non-significant effect of prebiotics, probiotics, and synbiotics on blood indices in laying hens, and Neveling et al. (2017) who reported non-significant differences in RBC, $\mathrm{Hb}, \mathrm{PCV}$, and $\mathrm{WBC}$ in broiler chickens fed chlotetracycline, and probiotics.

The lower ratio of heterophils to lymphocytes $(\mathrm{H}: \mathrm{L})$ in the control group (day 21 to 35 ) and the group fed S. cerevisiae indicated lower stress profile in birds of these groups (Campos et al., 2006). while the higher percent lymphocytes in these groups indicated stronger immunological status compared to the group fed antibiotics (Lee et al., 2004).

Table 3. Effect of antibiotics and probiotic on haematological indices of Abor acre broiler chicks

\begin{tabular}{|c|c|c|c|c|c|}
\hline Variable & Basal diet & S. cerevisiae & Neomycin & oxytetracycline & SEM \\
\hline $\mathrm{RBC}_{21}\left(\times 10^{9}\right)$ & 2.67 & 2.56 & 3.01 & 3.24 & 0.24 \\
\hline $\mathrm{RBC}_{35}$ & 2.80 & 2.89 & 3.02 & 2.78 & 0.24 \\
\hline $\mathrm{RBC}_{49}$ & 2.82 & 2.50 & 3.07 & 3.24 & 0.24 \\
\hline $\mathrm{PCV}_{21}(\%)$ & $32.25^{\mathrm{ab}}$ & $28.50^{b}$ & $35.00^{\mathrm{a}}$ & $37.00^{\mathrm{a}}$ & 2.53 \\
\hline $\mathrm{PCV}_{35}$ & 35.25 & 33.00 & 34.50 & 31.75 & 2.53 \\
\hline $\mathrm{PCV}_{49}$ & $32.25^{\mathrm{ab}}$ & $28.50^{b}$ & $35.00^{\mathrm{a}}$ & $37.00^{\mathrm{a}}$ & 2.53 \\
\hline $\mathrm{Hb}_{21}(\mathrm{~g} / \mathrm{dl})$ & 7.73 & 8.15 & 9.70 & 7.68 & 1.08 \\
\hline $\mathrm{Hb}_{35}$ & 7.43 & 8.63 & 8.05 & 7.70 & 1.08 \\
\hline $\mathrm{Hb}_{49}$ & 7.73 & 8.15 & 9.20 & 7.68 & 1.08 \\
\hline $\mathrm{WBC}_{21}\left(\times 10^{3}\right)$ & 5.77 & 6.09 & 6.94 & 6.76 & 7.48 \\
\hline$W_{B C}$ & 12.03 & 10.20 & 13.39 & 11.48 & 7.48 \\
\hline$W_{B C} C_{49}$ & 12.79 & 38.58 & 13.58 & 12.56 & 7.48 \\
\hline $\operatorname{Lym}_{21}(\%)$ & $68.00^{\mathrm{a}}$ & $63.00^{\mathrm{ab}}$ & $51.00^{c}$ & $54.00^{b c}$ & 3.92 \\
\hline $\operatorname{Lym}_{35}$ & $69.25^{\mathrm{a}}$ & $61.75^{a b}$ & $52.75^{b}$ & $57.50^{\mathrm{b}}$ & 3.92 \\
\hline $\operatorname{Lym}_{49}$ & $57.50^{\mathrm{ab}}$ & $66.25^{\mathrm{a}}$ & $65.00^{\mathrm{a}}$ & $52.00^{b}$ & 3.92 \\
\hline $\mathrm{Het}_{21}(\%)$ & $27.00^{c}$ & $34.25^{\mathrm{bc}}$ & $46.25^{\mathrm{a}}$ & $42.25^{\mathrm{ab}}$ & 4.14 \\
\hline $\mathrm{Het}_{35}$ & $26.50^{c}$ & $34.25^{b c}$ & $44.50^{\mathrm{a}}$ & $38.50^{\mathrm{ab}}$ & 4.14 \\
\hline $\mathrm{Het}_{49}$ & $40.75^{\mathrm{ab}}$ & $29.75^{c}$ & $32.00^{b c}$ & $45.50^{\mathrm{a}}$ & 4.14 \\
\hline Het:Lym 21 & $0.40^{\mathrm{b}}$ & $0.53^{b}$ & $0.93^{a}$ & $0.84^{a}$ & 0.13 \\
\hline Het:Lym 35 & $0.39^{c}$ & $0.57^{b c}$ & $0.91^{\mathrm{a}}$ & $0.72^{\mathrm{ab}}$ & 0.13 \\
\hline Het:Lym 49 & $0.73^{\mathrm{ab}}$ & $0.46^{c}$ & $0.53^{b c}$ & $0.88^{\mathrm{a}}$ & 0.13 \\
\hline
\end{tabular}


Table 4. Effect of antibiotics and probiotic supplementation on serum biochemical indices of Abor acre broiler chicks

\begin{tabular}{lllll}
\hline Variable & Basal diet & S. cerevisiae & Neomycin & oxytetracycline \\
\hline Albumin $(\mathrm{g} / \mathrm{dl})$ & $1.12 \pm 0.21$ & $1.18 \pm 0.24$ & $0.70 \pm 0.17$ & $1.10 \pm 0.24$ \\
Globulin $(\mathrm{g} / \mathrm{dl})$ & $1.83 \pm 0.38$ & $1.78 \pm 0.65$ & $1.97 \pm 0.28$ & $1.80 \pm 0.08$ \\
Total protein $(\mathrm{g} / \mathrm{dl})$ & $2.95 \pm 0.25$ & $2.95 \pm 0.54$ & $2.67 \pm 0.17$ & $2.90 \pm 0.23$ \\
Cholesterol $(\mathrm{mg} / \mathrm{dl})$ & $97.09 \pm 5.89$ & $100.5 \pm 13.19$ & $103.04 \pm 6.90$ & $95.32 \pm 9.41$ \\
Creatinine $(\mathrm{mg} / \mathrm{dl})$ & $0.35 \pm 0.47$ & $0.28 \pm 0.12$ & $0.25 \pm 0.06$ & $0.54 \pm 0.20$ \\
AST $(\mathrm{iu} / \mathrm{l})$ & $69.61 \pm 2.83$ & $66.80 \pm 2.29$ & $78.07 \pm 6.53$ & $69.21 \pm 5.50$ \\
ALT (iu/l) & $2.58 \pm 0.34$ & $4.53 \pm 1.11$ & $3.78 \pm 0.70$ & $3.50 \pm 1.10$ \\
\hline AST
\end{tabular}

AST: aspartate amino transferase; ALT: alanine amino transferase

The observed low values of $\mathrm{H}: \mathrm{L}$ in the probiotic group agrees with Beski and Al-Sardar (2015) who reported that probiotics ameliorate environmental stress, resulting in lower heterophil to lymphocyte ratio. He et al. (2019) reported higher IgA levels in broiler chickens fed probiotics compared to control and those fed antibiotics. IgA are antibodies generated by the activation of $B$ lymphocytes. In the same study, probiotic fed broiler chickens also had lower values of malondealdehyde (MDA) which indicates lower oxidative stress profile, and higher glutathione peroxidase and super oxide dismutase which indicate higher cellular antioxidant status (He et al., 2019). Islam et al. (2004) however, reported significant effects of probiotic supplementation in broiler diet on packed cell volume, haemoglobin concentration, and red blood cell count. Neveling et al. (2017) reported significant effects of probiotic and antibiotic treatments on percent lymphocyte of 19-day broiler chickens and non-significant effects in 29-day broiler chickens. The higher stress profile observed in the groups fed antibiotics could result from the continuous intake of antibiotics (Kalghatgi et al., 2013). It has been suggested that continuous administration of bactericidal antibiotics induce the formation of toxic reactive oxygen species (ROS). Bactericidal antibiotics cause cell death by oxidation of the guanine nucleotide pool. Kalghatgi et al. (2013) showed that bactericidal antibiotics cause mitochondrial dysfunction and ROS overproduction in mammalian cells leading to oxidative damage to DNA, proteins, and membrane lipids.

Serum biochemical indices did not differ significantly between treatment groups (Table 4) however, albumin tended to be lower in birds fed neomycin compared to other groups while total protein tended to be higher in the control group and the group fed probiotic compared to those fed neomycin. Birds fed oxytetracycline tended to have higher creatinine while AST tended to be higher in birds fed neomycin. These results were similar to those of Elsayed et al. (2014) who reported non-significant effects of antibiotic and probiotic feed additives on serum biochemical indices of broiler chickens, and Tang et al. (2017) who reported non-significant differences in AST and total serum protein in laying hens fed prebiotics, probiotics and synbiotics. Generally, the observed values were within the ranges for chickens as reported by previous studies (Albokhadaim et al., 2012; Rezende et al. 2017) and this suggests no special advantages from the antibiotic additives with regards to the metabolic functions of the experimental birds.

\section{Intestinal bacteria and Eimeria oocyst counts}

Intestinal, caecal, and combined caecal and intestinal bacteria counts differed significantly between treatment groups (Table 5). Colony count in the small intestine was highest in neomycin and control groups resulting in the highest bacteria population $\left(1.96 .25 \times 10^{5}\right.$ and $1.65 \times 10^{5} \mathrm{cfu} / \mathrm{ml}$, respectively) compared to 
oxytetracycline and probiotic groups which had the least colony count and hence the least bacteria population $\left(9.85 \times 10^{4}\right.$, and $1.12 \times 10^{5}$ $\mathrm{cfu} / \mathrm{ml}$, respectively). Birds fed S. cerevisiae, and neomycin had highest caecal bacteria colony counts $\left(1.66 \times 10^{5}\right.$, and $1.55 \times 10^{5} \mathrm{cfu} / \mathrm{ml}$, respectively) compared to control and oxytetracycline groups $\left(1.11 \times 10^{5}\right.$, and $9.60 \times$ $10^{4} \mathrm{cfu} / \mathrm{ml}$, respectively). Colony count from combined caecal and intestinal digester was highest in neomycin and probiotic groups (1.92 $\times 10^{5}$, and $1.65 \times 10^{5} \mathrm{cfu} / \mathrm{ml}$, respectively) and least in oxytetracycline group $\left(1.06 \times 10^{5}\right.$ $\mathrm{cfu} / \mathrm{ml})$. The lower bacteria counts from birds fed oxytetracycline suggest stronger antimicrobial effect compared to neomycin. Early in vitro studies (Gunnison et al., 1955; Williams, 1971) showed that some antibiotics (e.g., neomycin, polymyxin, and streptomycin) are more effective in the absence of nutrients while others (e.g., oxytetracycline and bacitracin) are not influenced by presence or absence of nutrients.

We hence speculate that the presence of nutrients may have reduced the bactericidal effects of neomycin in the present study. Other factors that may have reduced the effectiveness of neomycin include (1) the presence of sodium and potassium salts (Gunnison et al., 1955) which are components of poultry ration, and (2) the anaerobic and acidic $\mathrm{pH}$ of the lower intestinal environment which favour the efficacy of oxytetracycline but limit that of neomycin (Williams, 1971). The high bacteria counts observed in birds fed S. cerevisiae may have resulted from increased population of beneficial bacteria due to competitive exclusion and inhibition of pathogenic microflora (Ologhobo et al., 2015; Neveling et al., 2017). Koc et al. (2010) reported consistent increases in lactic acid bacteria and decreases in $E$. coli counts in ileum and caecum of broiler chickens fed yeast probiotic, and a prebiotic (mannan oligosaccharide). Neveling et al. (2017) reported lower levels of bioiluminescent $L$. monocytogenes in the gastrointestinal tract of broiler chickens fed a multistrain probiotic compared to control, and the group fed combined antibiotic agents. The authors suggested that the multistrain probiotic inhibited colonization and growth of bacterium in vivo due to production of organic acids, diacetyl, acetoin, hydrogen peroxide, and bacteriocins, or through competitive exclusion from the gastrointestinal tract. The low intestinal bacteria population (order, $10^{4}$ to $10^{5}$ $\mathrm{cfu} / \mathrm{ml}$ ) reported in the present study can be attributed to the culture-based technique employed which enumerates only culturable bacteria species and species that could grow on nutrient agar under aerobic condition (Shang et al., 2018; Yadav and Jha, 2019).

Table 5. Effect of antibiotics and probiotic supplementation on intestinal microbial count of Abor acre broiler chickens

\begin{tabular}{lllll}
\hline Variable & Basal diet & S. cerevisiae & Neomycin & Oxytetracycline \\
\hline Intestine & & & & \\
Mean colony count & $164.75 \pm 8.34^{\mathrm{b}}$ & $111.75 \pm 7.27^{\mathrm{c}}$ & $196.25 \pm 7.92^{\mathrm{a}}$ & $98.50 \pm 5.51^{\mathrm{c}}$ \\
Log (cfu/ml) & $5.22^{\mathrm{b}}$ & $5.05^{\mathrm{c}}$ & $5.29^{\mathrm{a}}$ & $4.99^{\mathrm{c}}$ \\
Emeria (oocyst/g) & $0.67 \pm 0.33$ & $0.25 \pm 0.25$ & $1.25 \pm 0.48$ & $0.50 \pm 0.29$ \\
Caecae & & & \\
Mean colony count & $111.25 \pm 5.02^{\mathrm{b}}$ & $149.75 \pm 5.02^{\mathrm{a}}$ & $165.75 \pm 7.65^{\mathrm{a}}$ & $96.00 \pm 6.25^{\mathrm{b}}$ \\
Log (cfu/ml) & $5.05^{\mathrm{b}}$ & $5.18^{\mathrm{a}}$ & $5.22^{\mathrm{a}}$ & $4.98^{\mathrm{c}}$ \\
Emeria (oocyst/g) & $1.33 \pm 0.67$ & $0.70 \pm 0.48$ & $1.25 \pm 0.48$ & $1.00 \pm 0.41$ \\
Intestine + caecae & & & \\
Mean colony count & $132.50 \pm 6.06^{\mathrm{c}}$ & $163.25 \pm 8.63^{\mathrm{b}}$ & $192.25 \pm 4.31^{\mathrm{a}}$ & $105.50 \pm 5.91^{\mathrm{d}}$ \\
Log (cfu/ml) & $5.12^{\mathrm{c}}$ & $5.21^{\mathrm{b}}$ & $5.28^{\mathrm{a}}$ & $5.02^{\mathrm{d}}$ \\
Emeria (oocyst/g) & $1.50 \pm 0.65$ & $0.50 \pm 0.29$ & $0.75 \pm 0.25$ & $1.50 \pm 0.50$ \\
\hline a & &
\end{tabular}

${ }^{a b c}$ significantly different means on the same row $(p<0.05)$. 
Corduk et al. (2008) reported coliform and total aerobic bacteria counts in the order $10^{5}$, and $10^{6} \mathrm{cfu} / \mathrm{g}$, respectively using enumeration in nutrient agar after incubation at $37^{\circ} \mathrm{C}$ for 48 hours.

\section{Sensitivity of Escherichia coli isolates}

The between group comparative sensitivity of $E$. coli isolates to neomycin and oxytetracycline revealed significantly different diameter of inhibition zones by the antibiotic agents (Table 6). Escherichia coli from control group and birds fed probiotic had the highest diameter of inhibition zone by neomycin $(22.30$ \pm 2.90 and $18.00 \pm 2.90 \mathrm{~mm}$, respectively) and oxytetracycline $(24.30 \pm 2.90$ and $19.30 \pm$ $2.90 \mathrm{~mm}$, respectively). Organisms from birds fed neomycin had diameter of inhibition zone of $11.70 \pm 2.90 \mathrm{~mm}$ by oxytetracycline while those from birds fed oxytetracycline had inhibition zone diameter of $14.30 \pm 2.90 \mathrm{~mm}$ by neomycin.

Escherichia coli from the groups fed neomycin, and oxytetracycline, were least inhibited by neomycin (zone diameter: $5.70 \pm$ $2.90 \mathrm{~mm}$ ), and oxytetrcycline (zone diameter: $3.39 \pm 2.90 \mathrm{~mm})$, respectively. Escherichia coli from control and probiotic groups were therefore sensitive to neomycin and intermediately sensitive to oxytetracycline while organisms from neomycin group were resistant to neomycin and intermediately sensitive to oxytetracycline (CLSI, 2013). On the other hand, E. coli from oxytetracycline group were resistant to both neomycin and oxytetracycline. These results indicate that oxytetracycline had a stronger selection pressure for resistant bacteria phenotypes, and that the use of antibiotics for growth enhancement in the present study resulted in the development of resistant bacteria phenotypes and expression of antimicrobial resistant genes in agreement with other studies (Diarra and Malouin 2014; Cosby et al 2015). It has been reported that the use of antibiotics for growth enhancement in animals creates a selection pressure that favours the survival and spread of antimicrobial resistant bacteria phenotypes (Neveling et al., 2017; He et al., 2019). The continuous intake of antibiotics through feed in the present study may have constituted a stress factor for bacteria leading to increased frequency of mutations, and recombinations, and the emergence of resistant bacteria phenotypes (Diarra et al. 2007; Wistrand-Yuen et al., 2018). Fairchild et al. (2005) had reported the presence and increased expression of tetracycline resistance determinant genes in E. coli and Campylobacter jejuni isolated from caecal digester of chickens fed oral tetracycline antibiotic. The observed partial antimicrobial resistance of $E$. coli from control and probiotic groups to oxytetracycline could result from acquisition of resistant phenotypes or resistance genes from the environment (litter material, feed, water, feeders, drinkers, and farm personnel). These findings by the present study have grave consequences for animal production, public health and the therapeutic use of antibiotics in animals and man.

The environmental limitations to the antimicrobial effects of neomycin presented earlier could also enhance the development of resistance to this antibiotic and this may be an additional explanation for the higher colony counts (higher bacteria populations) observed in the group fed neomycin. Kumar et al. (2018) reported that birds fed bacitracin dimethyl salicylate had higher prevalence of food borne pathogens like Campylobacter and Salmonella species and did not differ in number of bacterial phyla present in the intestinal tract compared to untreated control group while Neveling et al. (2017) observed higher levels of bioiluminescent $L$. monocytogenes in the intestinal tracts of broilers fed a combination of antibiotics (sulphadiazine, colistin and trimethoprim) compared to control group and those fed probiotics. 
Table 6. Effect of probiotic and antibiotic supplementation on diameter $(\mathrm{mm})$ of zone of inhibition and sensitivity of $E$. coli from Abor acre broiler chickens

\begin{tabular}{lllll}
\hline Test antibiotic & Basal diet & S. cerevisiae & Neomycin & Oxytetracycline \\
\hline Neomycin $^{1}$ & $22.30 \pm 2.90^{\mathrm{a}}$ & $18.00 \pm 2.90^{\mathrm{ab}}$ & $5.70 \pm 2.90^{\mathrm{c}}$ & $14.30 \pm 2.90^{\mathrm{b}}$ \\
Sensitivity & $\mathrm{S}$ & $\mathrm{S}$ & $\mathrm{R}$ & $\mathrm{I}$ \\
Oxytetracycline $^{2}$ & $24.30 \pm 2.90^{\mathrm{a}}$ & $19.30 \pm 2.90^{\mathrm{ab}}$ & $11.70 \pm 2.90^{\mathrm{b}}$ & $3.39 \pm 2.90^{\mathrm{c}}$ \\
Sensitivity & $\mathrm{I}$ & $\mathrm{I}$ & $\mathrm{R}$ & $\mathrm{R}$ \\
\hline
\end{tabular}

a,b,c: significantly different means on the same row ( $p<0.05)$, S: sensitive, R: resistant, I: intermediate; ${ }^{1}$ Cut off zone diameter $(\mathrm{mm}): \leq 12=\mathrm{R}, 13-16=\mathrm{I}, \geq 17=\mathrm{S} ;{ }^{2}$ Cut off zone diameter $(\mathrm{mm}): \leq 15=\mathrm{R}, 16-25=\mathrm{I}, \geq 26=\mathrm{S}$.

\section{Mortality}

Percent mortality did not differ significantly $(p>0.05)$ between treatments across the age periods. Mortality tended to be higher at $42 \mathrm{~d}$ of age when birds in the control group had mortality of $5.50 \%$ as against $3.70 \%$ for neomycin, and $0.00 \%$ other treatments (Table 7).

Apart from this, mortality was generally low (range: 0.00 to $3.70 \%$ ) across treatment groups at the other age periods. The lowest mortality observed in birds fed S. cerevisiae reflects the beneficial effects of probiotics on health and survival of broiler chickens. Bonsu et al (2012) reported lower percent mortality in broiler chickens fed probiotics (direct fed microbials) compared to the control diet. Giggs and Jacobs (2005) however reported non-significant effect of treatment on percent mortality in chickens fed antibiotic growth promoters, probiotics and basal diet.

Table 7. Mortality in Abor acre broiler chicks fed basal diet or diet supplemented with probiotic and antibiotics

\begin{tabular}{lllll}
\hline Age (days) & Basal diet & S. cerevisiae & Neomycin & Oxytetracycline \\
\hline 28 & $0.00 \pm 0.00$ & $0.00 \pm 0.00$ & $0.00 \pm 0.00$ & $3.33 \pm 3.33$ \\
35 & $0.00 \pm 0.00$ & $3.33 \pm 3.33$ & $3.70 \pm 3.70$ & $0.00 \pm 0.00$ \\
42 & $5.50 \pm 3.22^{\mathrm{a}}$ & $0.00 \pm 0.00^{\mathrm{c}}$ & $3.70 \pm 3.70^{\mathrm{bc}}$ & $0.00 \pm 0.00^{\mathrm{c}}$ \\
49 & $0.00 \pm 0.00$ & $0.00 \pm 0.00$ & $0.00 \pm 0.00$ & $3.33 \pm 3.33$ \\
\hline
\end{tabular}

$a, b, c:$ significantly different means on the same row $(p<0.05)$

\section{Conclusions}

Probiotics should be used in place of antibiotics as feed additives for broiler chicken production to enhance growth performance. The use of antibiotics in feed to enhance growth performance should be discouraged to minimize the development and spread of antibiotic resistant bacteria phenotypes.

\section{References}

Albokhadaim I., T. Althnaian and S.M. El-Bahr. 2012 Investigation of selected biochemical parameters of local chickens with different age and sex in Alahsa, Saudi Arabia. Pakistan Journal of Biological Sciences 15 (17): 827-832.

Ashayerizadeh A., N. Dabiri, O. Ashayerizadeh, K.H. Mirzadeh, H. Roshanfekr and M. Mamooee. 2009 Effect of dietry antibiotic, probiotic and prebiotic as growth promoters on growth performance, carcass characteristics and haematological indices of broiler chickens. Pakistan Journal of Biological Sciences 12 (1): 52-57.

Beski S.S.M., S.Y.T. Al-Sardary. 2015 Effects of dietary supplementation of probiotic and symbiotic on broiler chicken haematology, and intestinal integrity. Int J Poult Sci 14 (1): 31-36.

Bonsu F.R.K., S.A. Osei, D.B. Okai, J. Baah. 2012 Effect of direct-fed microbials and antibiotics supplementation on the health status and growth performance of broiler chickens under hot humid environmental conditions. Int J of Lsk Prod 3 (6): 66-71.

Campos J.L., M.G. Gil, S.G. Davila, I. Munoz. 2006 The genetics of three welfare indicators: tonic immobility duration, heterophil to lymphocyte ratio, and fluctuating asymmetry. WPS J, suppl. 62: 606-611.

Cheesbrough M. 1998 District Laboratory Practice in Tropical Countries, part 1. Cambridge University Press. 
CLSI. (2013). Performance Standards for Antimicrobial Susceptibility Testing: TwentyThird Informational Supplement. CLSI Document M100-S22. Clinical and Laboratory Standards Institute, Wayne, PA.

Corduk M., N. Ceylan, N. Dede and O.Y. Tel. 2008 Effects of novel feed additives on performance, carcass traits and E. coli, aerobic bacteria and yeast counts in broilers. Arch. Geflugelk 72 (2). S. 61-67.

Cosby D.E., N.A. Cox, M.A. Harrison, J.L. Wilson, R.J. Buhr, P.J. Fedorka-Cray. 2015 Salmonella and antimicrobial resistance in broilers: A review. J Appl Poult Res 24: 408-426.

Cruickshank R.J., B.P. Marion, R.H.A. Jwan. 1975 Centrifuges, calorimeters, bacteria counts in medical microbiology $12^{\text {th }}$ ed. Pp. 301-307.

Diarra M.S., F. Malouin. 2014 Antibiotics in Canada poultry production and anticipated alternatives. Front Microbiol 5: 1-15.

Diarra M.S., F.G. Silversides, F. Diarrassouba, J. Pritchard, L. Masson, R. Brousseau, C. Bonnet, P. Delaquis, S. Bach, B.J. Skura, E. Topp. 2007 Impact of feed supplementation with antimicrobial agents on growth performance of broiler chickens, Clostridium perfringes and enterococcus counts, and antibiotic resistance phenotypes and distribution of antimicrobial resistance determinants in Escherichia coli isolates. Appl Envt Microbiol 73 (20): 6566-6576.

El-Hammady H.Y., M. El-Sagheer, H.H.M. Hassanien, H.A. Hassan. 2014 Performance and carcass traits of broilers supplemented with probiotic and neomycin antibiotic. Egypt J Anim Prod 51 (2): 107-114.

Elsayed M., A. Elkomy, M. Aboubakr and M. Morad. 2014 Tissue residues, haematological and biochemical effects of tilmicosin in broiler chicken. Veterinary Medicine International. Doi: org/10: 1155/2014/502892.

Fairchild A.S., J.L. Smith, U. Idris, J. Lu, S. Sanchez, L.B. Purvis, C. Hofacre, M.D. Lee. 2005 Effects of orally administered tetracycline on the intestinal community structure of chickens and on tet determinant carriage by commensal bacteria and Campylobacter jejuni. Appl Envt Microbiol 71 (10): 5865-5872.

Giggs J.P., J.P. Jacobs. 2005 Alternatives to antibiotics for organic poultry production. The J Appl Poult Product 14: 150-156.

Gunal M., G. Yayli, O. Kaya, N. Karahan, O. Sulak. 2006 The effects of antibiotic growth promoter, probiotic or organic acid supplementation on performance, intestinal microflora and tissue of broilers. Int J Poult Sci 5: 149-155.

Gunnison J.B., E. Kunishige, V.R. Coleman, E. Jawetz. 1955 The mode of action of antibiotic synergism and antagonism: the effect in vivo on bacteria not actively multiplying. J Gen Microbiol 13: 509518.

He T., S. Long, S. Mahfuz, D. Wu, X. Wang, X. Wei and X. Piao. 2019 Effects of probiotics as antibiotics substitutes on growth performance, serum biochemical parameters, intestinal morphology, and barrier function of broilers. Animal 9: 985; doi: 10.3390/ani9110985.

Islam M.W., M.M. Rahmen, S.M.L. Kabir, S.M. .Kamruzzan, S.N. Islam. 2004 Effects of probiotics supplementation on growth performance and certain haemato-biochemical parameters in broiler chickens. Bangla J Vet Med 2 (1): 39-43.

Jadhav K., K.S. Sharma, S. Katoch, V.K. Sharma and B.G. Mane. 2015 Probiotics in broiler poultry feeds: A review. Journal of Animal Nutrition and Physiology 1: 4-16.

Kalghatgi S., C.S. Spina, J.C. Costello, M. Liesa, J.R. Morones-Ramirez, S. Slomovic, A. Molina, O.S. Shirihai and J.J. Collins. Bactericidal antibiotics induce mitochondria dysfunction and oxidative damage in mammalian cells. Sci Transl Med. 5 (192): 192ra85. Doi: 10.11261scitranslmed.3006055.

Koc F., H. Samil, A. Okur, M. Ozduven, H. Akyurek, N. Senkoylu. 2010 Effect of Saccharomyces cerevisiae and/or mannanoligosaccharides on performance, blood parameters and intestinal microbiota of broiler chicks. Bulg J Agric Sci 16: 643-650.

Kumar S., C. Chen, N. Indugu, G.O. Werlong, M. Singh, W.K. Kim, H. Thippareddi. 2018. Effect of antibiotic withdrawal in feed on chicken gut microbial dynamics, immunity, growth performance and prevalence of foodborne pathogens. PloS ONE 13 (2): e0192450.

Lee J.W., J.G. Shin, E.H. Hee, H.E. Kang, I.B. Yim, J.Y. Kim, H.G. Joo, H.J. Woo. 2004 Immunomodulatory and antitumor effects in vivo by the cytoplasmic fraction of Lactobacillus and Bifidobacterium longum. J Vet Sci 5 (1): 41-48.

Mohamed M.A., E.F. El-Daly, N.A. Abdel Azeem, A.W. Youssef, H.M.A. Hassan. 2014 Growth performance and histological changes in ileum and immune related organs of broilers fed organic acid or antibiotic growth promoters. Int J Poult Sci 13 (10): 602-614.

Neveling D.P., L. van Emmenes, J.J. Ahire, E. Pieterse, C. Smith, and L.M.T. Dicks. 2017 Safety assessment of antibiotic and probiotic feed additives for Gallus gallus domesticus. Scientific Reports 7. Doi 10.1038/s41598-017-12866-7.

Odefemi T.R. 2016 Performance response and carcass characteristics of broilers fed dietary antibiotics, probiotics and prebiotics. European 
Journal of Agriculture and Forestry Research 4 (1): 27-36.

Ologhobo A.D., L.C. Adighibe, O.O. Adeleye, I.O. Adejumo. 2015 Impact of Saccharomyces cerevisiae (yeast) supplementation on varied cereal-based broiler starter diets on gut microflora and morphology. J Sci Res and Reports 6 (1): 73-81.

Rezende M.S., a.v. Mundim, B.B. Fonseca, R.I. Miranda, W. Oliveira Jr and C.G.Lelli. 2017 Profile of serum metabolites and proteins of broiler breeders in rearing age. Brazilian Journal of Poultry Science 19 (4): 583-586.

Shang Y., S. Kumar, B. Oakley, W.K. Kim. 2018 Chicken gut microbiota: importance and detection technology. Front Vet Sci 5: 254. Doi:10.3389/fvets.2018.00254.

Tang S.G.H., C.C. Sieo, K.Ramasamy, W.Z. Saad, H.K.Wong and Y.W. Ho. 2017 Peroformance, biochemical and haematological responses, and relative organ weights of laying hens fed diets supplemented with probiotic, probiotic and symbiotic. BMC Veterinary Research 13: 248-259.

Toghyani M., M. Toghyani, S.A. Tabeidian. 2011 Effect of probiotic and antibiotic growth promoter substitutions on productive and carcass traits of broiler chicks. International Conference of Food Engineering and Biotechnology IPCBEF 9, Singapore.

Williams B.J.. 1971 Factors which influence synergism by neomycin and oxytetracycline. Appl Microbiol 21 (4): 668-672.

Wistrand-Yuen E., M. Knopp, K. Hjort, S. Koskiniemi, O.G. Berg, and D.I. Andersson. 2018. Evolution of high-level resistance during low-level antibiotic exposure. Nat Com 9: 1599. Doi: 10.1038/s41467-018-04059-1.

Yadav S., R. Jha. 2019. Strategies to modulate the intestinal microbiota and their effects on nutrient utilization, performance, and health of poultry. J Anim Sci and Biotech 10 (2): 1-11. 